$$
\begin{gathered}
\text { デジタルカラー画像解析による } \\
\text { 締固め過程のコンクリート表面気泡の評価 }^{\dagger}
\end{gathered}
$$

\author{
前田 智之* 原田 沙里 $* *$ 森内 麻衣** \\ 藤原 正稔 $*$ 吉武 勇 $* * *$
}

\title{
Digital Image Analysis of Concrete Bugholes under Vibrating Consolidation
}

by

\author{
Tomoyuki MAEdA*, Sari HARADA**, Mai MoriUCHi***, \\ Masanori FuJIWARA* and Isamu YoshitAKE****
}

The present study aims to improve surface quality of tunnel lining concrete. The study developed an image analysis to detect and evaluate bugholes on concrete surface. The developed system calculates RGB value of colored images of concrete having bugholes. The study examines the accuracy and effectiveness by comparing the system to a binary image analysis. The comparative result shows that the developed system has higher accuracy than the binary image analysis. To examine generation of concrete bugholes, the developed system was employed in a vibrating consolidation test. The primary observation is that relatively small bugholes remained on concrete surface while large bugholes disappeared by vibrating consolidation.

\section{Key words:}

Bugholes, Digital image analysis, Tunnel lining concrete, Surface quality

\section{1 緒訔}

高度経済成長期に構築された社会資本が一斉に老朽を 迎え, 効率の良い維持管理が必要とされる中, 新設するコ ンクリート構造物は, ライフサイクルコストの最小化や 第三者に対する事故防止を目的に長期的な耐久性の確保 が求められている。コンクリートの耐久性には物質移動 抵抗性が関わり，表層品質と密接な関連性があるといわ れており，耐久性とあわせて表層品質が注目されている。 またコンクリートの表層品質を検查診断する技術は種々 あるが，リバウンドハンマー試験や表層透気試験法 （Torrent 法）などがしばしば用いられる。近年では目視 調查が再注目され，コンクリートの表層品質をグレーデ イングによって評価する手法も提案されている1).

コンクリートの表層品質の目視調査で評価する項目に は,「ひび割れ」、「コールドジョイント」,「目違い」,「砂 すじ」,「豆板」、「表面気泡」などがある2)，そのうち「表 面気泡」は，打込み中の締固め不足が要因のひとつといわ れ，様々な対策がとられているが 3),4)，トンネル覆工コン クリート側壁部において, 表面気泡が発生しやすいにも 関わらず，気泡を低減する実用的な方法が確立されてな いのが現状である ${ }^{5}$. また，一般的な構造物においても一 部では対策がとられるものの，コンクリートの仕上がり 面が傾斜している籄所や締固めが困難な箇所，打設高さ の高い箇所では表面気泡が発生しや寸く, さらなる施工 技術の改善が求められるものと考えられる。 そこで本研
究では，コンクリート表面気泡の発生特性を調ベること で, その効率的な低減法に寄与寸るため, 振動締固め過程 における表面気泡の発生量を定量的に調查した。 具体的 には,トンネル覆工側壁部を模擬した試験型枠 6)を用いて コンクリート供試体を作製し，型枠の調査面に透明アク リル板を用いて可視化することで, 経時的な気泡発生量 の変化を定量的に調心， 締固め過程における表面気泡発 生特性の評価を試みた。

これまで,コンクリート表面気泡の定量化にあたり，目 視調查に加え, 撮影画像の二值化処理や感圧紙による測 定による画像解析が行われてきた7). 目視調查では評価者 によって評価結果にばらつきがあり, 定量評価に限界が あった. また, 従来の画像解析法では表面気泡以外のコン クリート表層の不具合, 污れや影等, 表面気泡以外の状態 を誤検出することなどの課題も残されていた.

そこで本研究では, 表面気泡発生量の定量評価と評価 結果の誤差の影響を低減するため, デジタルカメラで撮 影したカラー画像の RGB 值を用いて表面気泡を検出する 方法を考案した. 本手法を用いて, 締固め過程におけるコ ンクリート表面の状態を透明アクリル板型枠越しに撮影 した画像を解析することで, 従来手法にみられた表面気 泡の誤検出を低減し, 締固め過程のコンクリートの表面 気泡を測定・定量評価を可能とした. 本研究で開発したコ ンクリート表面気泡判定ソフトウェア (以下, 気泡判定ソ フトと略記）を使用した調查, 評価に先立ち, 従来の手法

\footnotetext{
$\dagger$ 原稿受理 平成28年 3月 28日 Received Mar.28,2016 C2017 The Society of Materials Science, Japan

* 五洋建設(株)广112-8576東京都文京区後楽, Penta-Ocean CO., Bunkyou-ku, Tokyo, 112-8576.

** 山口大学大学院７ 755-8611宇部市常盤台, Grad. School of Yamaguchi Univ., Tokiwadai, Ube, 755-8611

*** 鉄道・運輸機構 (元 山口大学工学部) † 532-0003大阪市淀川区, Japan Railway Const. Trans. and Tech. Agency, Yodogawa-ku, Osaka, 532-0003

**** 正 会員 山口大学大学院７755-8611宇部市常盤台, Grad. School of Yamaguchi Univ., Tokiwadai ,Ube, 755-8611.
} 
との調査結果を比較することで，気泡判定ソフトによる 検出精度を確認した。

\section{2 実験概要}

\section{$2 \cdot 1$ 実験装置}

本実験で使用した型枠をFig.1に示す。型枠は表面気泡 が発生しやすいトンネル覆エコンクリートの側壁部3), 8) を模擬し，コンクリート仕上がり面（型枠角度）を $30^{\circ} に$ 傾斜させ，内空断面側に相当する型枠上面を評価対象面 とした，型枠の材質は，底面を含む全5面のうち4面は実 際のトンネルの覆工に用いられる移動式型枠 (セントル) に使用する鋼板を, 評価対象とする型枠にはコンクリー 卜充填過程の状態を観察するため, 透明で表面が平滑な アクリル板 (10mm厚) を使用した. コンクリート供試体 の寸法は高さ $750 \mathrm{~mm}$, 幅 $300 \mathrm{~mm}$, 厚さを標準的な覆工コ ンクリート設計厚である $300 \mathrm{~mm}$ とた。 なお，コンクリ ートの打込みは実験室内で行った.

\section{$2 \cdot 2$ 実験方法}

実験室内で，コンクリートを前述した型枠に打ち込み， 供試体を作製した. 1 層の打込み高 $750 \mathrm{~mm}$ でコンクリー 卜を型枠上面から打ち込んだ。振動締固め過程における 表面気泡の発生状況を観察するため, 通常の締固め時間 より長い 420 秒間（60 秒 $\times 7$ 回）締固めた. 振動締固め には棒状バイブレータ（径 $28 \mathrm{~mm}$ ，周波数 $220 \sim 280 \mathrm{~Hz}$ ) を用い, 打込み完了後は室内で気中養生し, 約 18 時間 後に脱型した.

振動締固め中は, デジタルカメラ（3264×2448 画素） を用いて評価対象面を 10 秒間隔で撮影した。この撮影 画像について表面気泡判定ソフトを用いて解析し, 表面 気泡を検出した. Fig.2 に示すように評価領域を供試体下 端から $75 \mathrm{~mm}$ 上方の $300 \times 300 \mathrm{~mm}$ とし, 気泡判定ソフト により評価領域中の表面気泡面積率 (表面気泡と判定さ れた面積／評価領域全面積）および表面気泡の個数を求 めた.

\section{$2 \cdot 3$ コンクリート配合と練混ぜ方法}

使用した材料の物性值をTable.1に示すとともに，実験 用コンクリート配合をTable.2に示す。実トンネルに採用 された覆工コンクリートの配合を参考に設定し，目標強 度を $21 \mathrm{~N} / \mathrm{mm}^{2}$ (材齢 28 日)，目標スランプを $15 \pm 2.5 \mathrm{~cm}$, 空気量を $4.5 \pm 1.5 \%$ とした。粗骨材の質量混合比は $\mathrm{G}_{1}$ : $\mathrm{G}_{2}: \mathrm{G}_{3}=4: 3: 3$ とした。コンクリートの練混ぜには, 容 量50Lの二軸強制練りミキサを使用した。練混ぜは, 細骨 材とセメントを30秒空練りした後, 水を加えて 60 秒, そ の後粗骨材を加えて120秒，合計210秒間とした。

\section{3 撮影画像を用いた表面気泡の検出・評価方法}

これまで表面気泡の定量評価方法として, 圧力測定つ イルムを用いた方法6)やデジタルカメラ撮影画像の二值 化 (モノクロ化) 処理による方法などが用いられてきた. しかし，圧力測定フィルム法はコンクリート表面の凸部 に対応できないことや数 $\mathrm{mm}$ 以下の小さな気泡の誤認識, 撮影画像の二值化処理法では，コンクリート表面の污れ， 色むらや影の誤認識などの課題があった，そのため測定
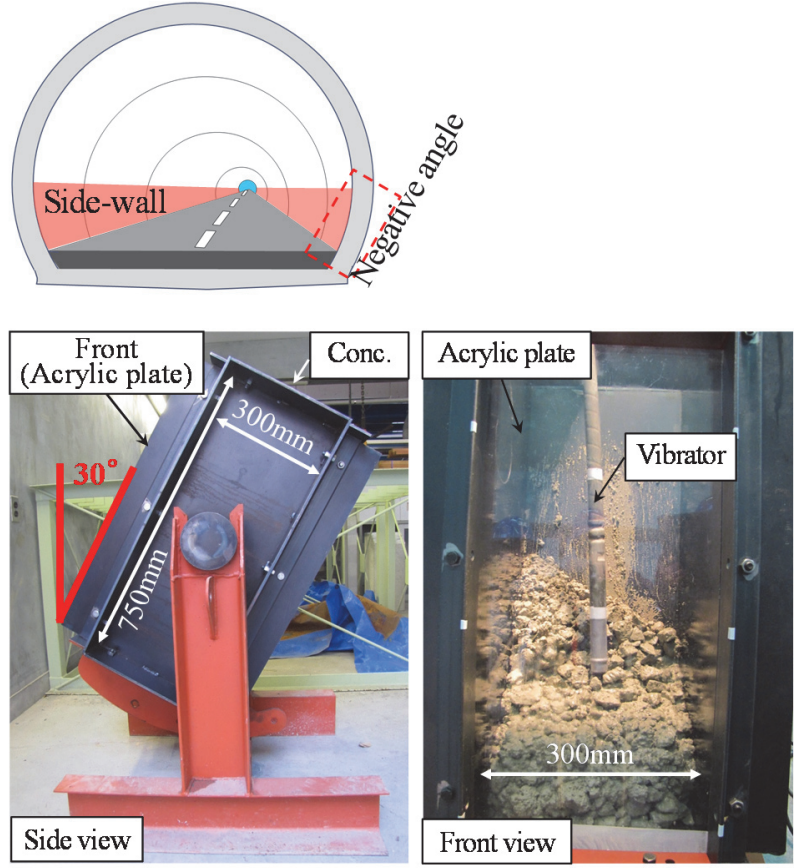

Fig.1 Steel form simulating sidewall of tunnel lining.

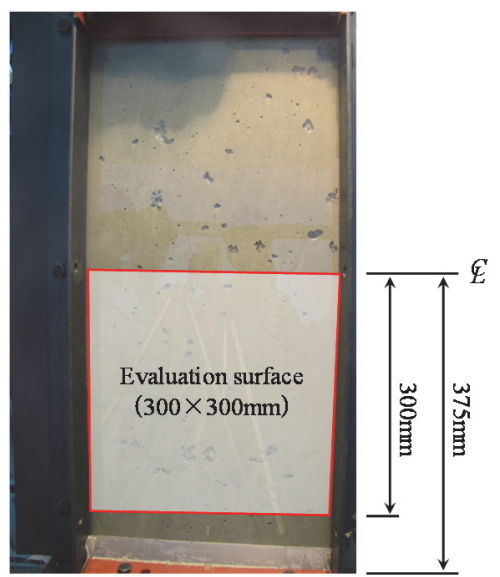

Fig.2 Evaluation area of concrete.

精度が低くなり，結果にばらつきが生じやすいものであ った．本研究では，表面気泡判定の精度向上と定量評価 を目的に，デジタルカメラで撮影したカラー画像を用い て表面気泡を判定する気泡判定ソフトを開発した．以下 に開発した気泡判定ソフトの特徴および解析精度につ いて概説する.

\section{$3 \cdot 1$ 気泡判定ソフトの特徵}

気泡判定ソフトは, デジタルカメラで撮影した評価対 象面のカラー画像データについて, 演算処理することで 表面気泡の判定を自動的に行うソフトウェアである. 表 面気泡の判定には撮影画像のRGB值を用いる．撮影した 評価対象面内にある典型的な表面気泡を選定し，選定し た範囲内の画像の画素ごとの $\mathrm{R}$ 值, $\mathrm{G}$ 值, $\mathrm{B}$ 值の平均值を それぞれ求め, 表面気泡と判定するための基準值に設定 する．気泡の判定は一画素ごと行い，基準值に対してR 值，G值，B值のすべてが下回った場合，その画素を表面 気泡と判定する.さらに撮影画像の画素落ち対策として, 表面気泡と判定された画素が近接してある場合, 表面気 泡と判定された画素間の距離に応じて画素同士を結合 
Table.1 Materials.

\begin{tabular}{|c|c|c|}
\hline Materials & Symbol & Properties \\
\hline Cement & $\mathrm{C}$ & $\begin{array}{c}\text { Blast-furnace slag cement (B), } \\
\text { density: } 3.04 \mathrm{~g} / \mathrm{cm}^{3}\end{array}$ \\
\hline $\begin{array}{c}\text { Fine } \\
\text { aggregate }\end{array}$ & $\mathrm{S}$ & Sea sand, density: $2.60 \mathrm{~g} / \mathrm{cm}^{3}$ \\
\hline \multirow{3}{*}{$\begin{array}{l}\text { Coarse } \\
\text { aggregate }\end{array}$} & $\mathrm{G}_{1}$ & $\begin{array}{c}\text { Crushed sandstone, } \\
\text { Max.-Min. size : } 40-20 \mathrm{~mm} \\
\text { Density: } 2.72 \mathrm{~g} / \mathrm{cm}^{3} \\
\end{array}$ \\
\hline & $\mathrm{G}_{2}$ & $\begin{array}{l}\text { Crushed sandstone, } \\
\text { Max.-Min. size : } 20-15 \mathrm{~mm} \\
\text { Density: } 2.73 \mathrm{~g} / \mathrm{cm}^{3}\end{array}$ \\
\hline & $\mathrm{G}_{3}$ & $\begin{array}{c}\text { Crushed sandstone, } \\
\text { Max.-Min. size: } 15-5 \mathrm{~mm} \\
\text { Density: } 2.70 \mathrm{~g} / \mathrm{cm}^{3}\end{array}$ \\
\hline \multirow{2}{*}{ Admixture } & WRA & Water reducing agent \\
\hline & $\mathrm{AE}$ & Air entraining agent \\
\hline
\end{tabular}

Table.2 Mixture proportion of lining concrete.

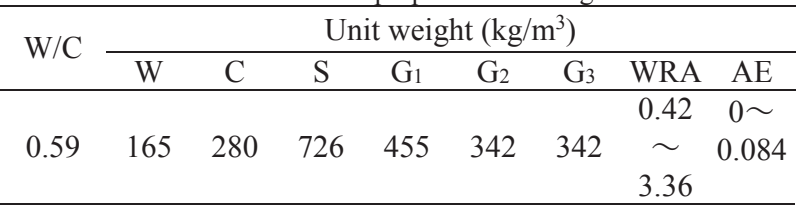

し，ひとつの表面気泡と判定した，本研究では，画素間 の距離が1画素分であれば，ひとつの表面気泡と判定し，

これらの画素を結合する処理を行った.

RGB值を利用することで，表面気泡の基準值を二值化 処理のように二極化せず詳細に設定することができる ため，撮影条件等によって異なる表面気泡の色や濃淡に
対応することができる，これにより，二值化処理では誤 認識されていたコンクリート表面の污れ，色むら，影な どの表面気泡ではない要素（画素）を排除しながら表面 気泡を検出できるようになった. 検出精度の詳細は後述 する.

\section{$3 \cdot 2$ 気泡判定ソフトを用いた表面気泡の測定方法}

撮影には解像度が3264×2448画素のデジタルカメラを 用いた，撮影は実験室内で実施し，照明等を用いず自然 光のみとした. Fig.3に示すように評価対象面からデジタ ルカメラのレンズまでの距離が約 $500 \mathrm{~mm}$ となるように カメラを三脚で固定し，評価領域の横に鋼尺を設置して 撮影した。撮影画像を気泡判定ソフトで読み込み，撮影 画像端部のゆがみによる判定誤差を排除するため測定 範囲外をマスキング処理し, 自動解析した。撮影画像中 の標尺の目盛りから尺度を取得することで，1画素あた

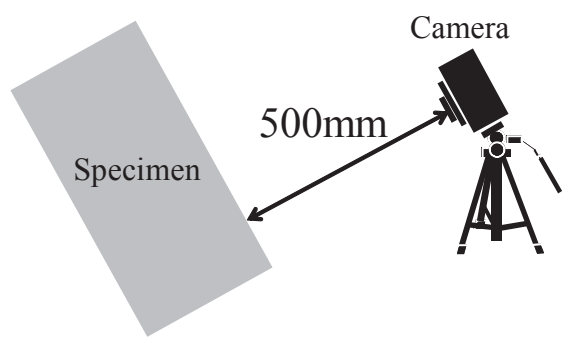

Fig.3 Photographic situation.

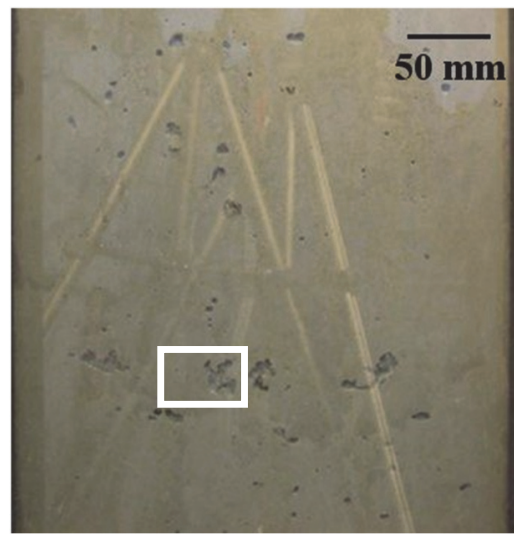

Original

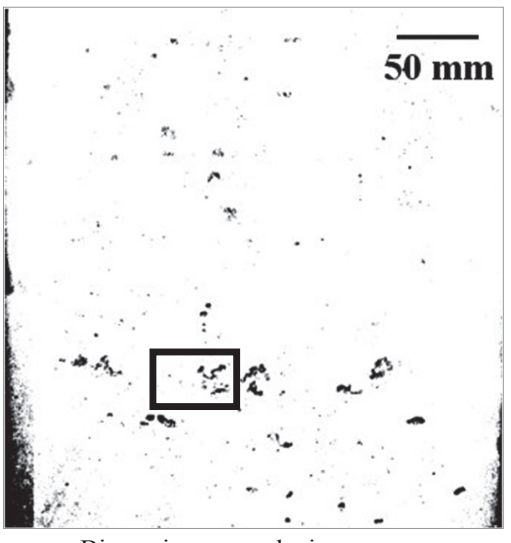

Binary image analysis (30sec)

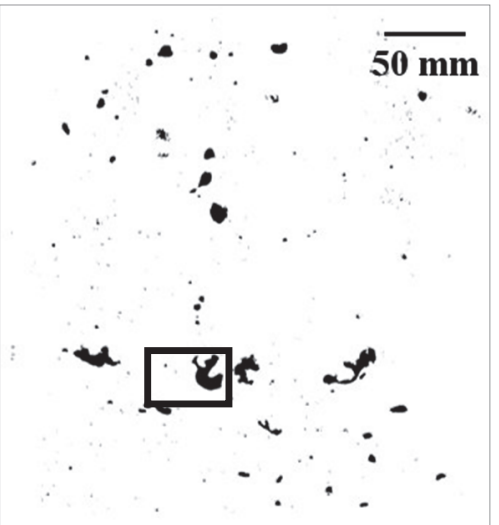

Developed analysis

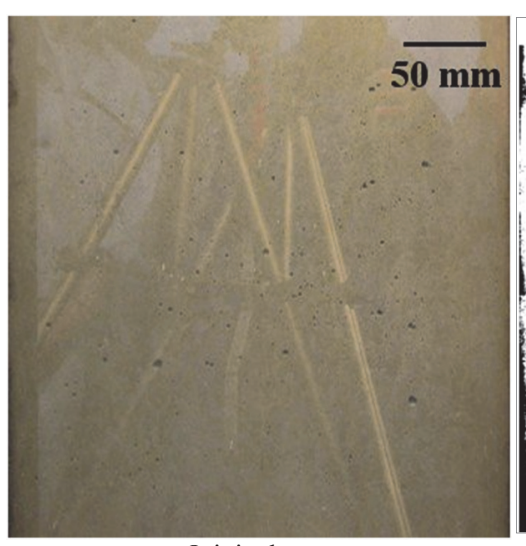

Original

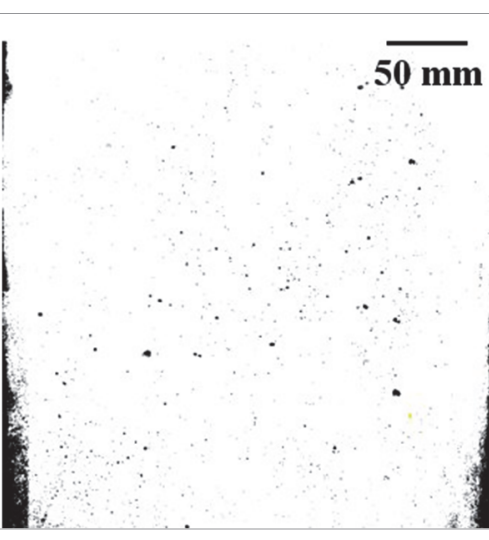

Binary image analysis $(180 \mathrm{sec})$ .$\overline{50 \mathrm{~mm}}$

Developed analysis

Fig.4 Comparison of image analysis. 


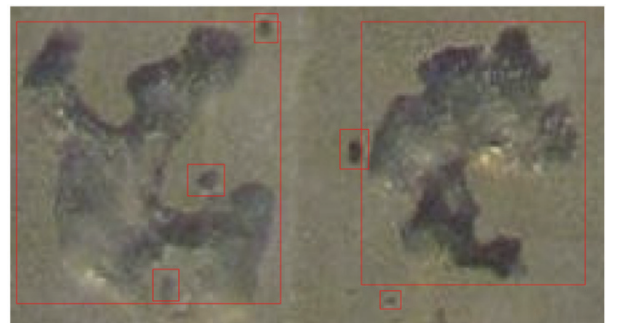

a) Color image analysis
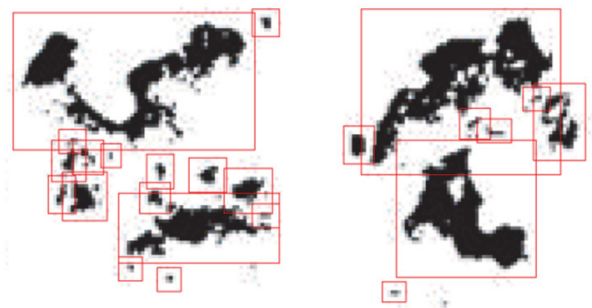

b) Binary image analysis

Fig.5 Photographic situation.

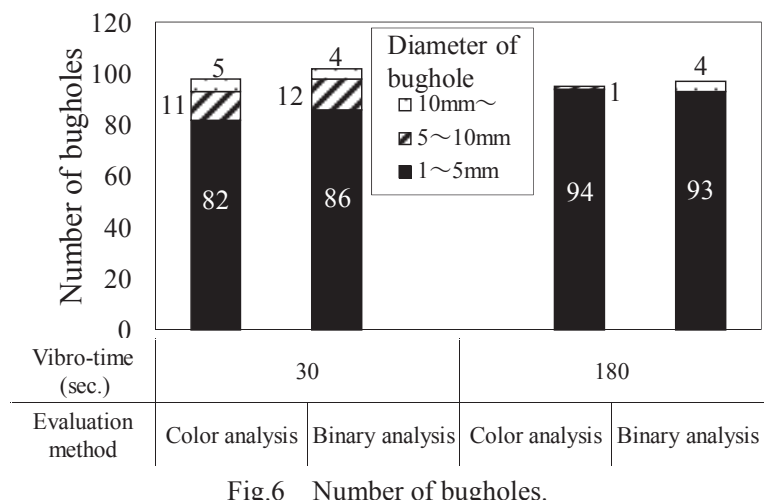

Fig.6 Number of bugholes.

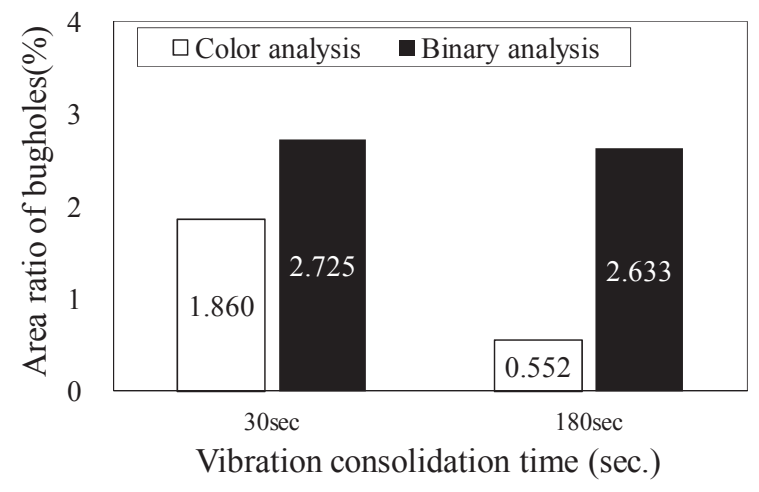

Fig.7 Number and area ratio of bugholes.

りの寸法・面積を求め, 表面気泡と判定された画素の集 合体の面積 $\left(\mathrm{mm}^{2}\right)$ を算出した。そして取得した気泡面 積 $\left(\mathrm{mm}^{2}\right)$ を円換算で気泡径 $(\mathrm{mm})$ に換算し, 円換算直 径 $1 \mathrm{~mm}$ 以上の表面気泡個数を気泡径別に求めた.

\section{$3 \cdot 3$ 検出精度}

本実験では振動締固め中のコンクリート面を, 透明ア クリル板を介して撮影した。アクリル板を介するため, 反射光など多数の色が混在することとなる．コンクリー 卜表面気泡の評価に先立ち，開発した気泡判定ソフトを 用いて締固め過程におけるアクリル板越しに撮影した 画像の気泡検出精度を確認した。アクリル板越しでは,

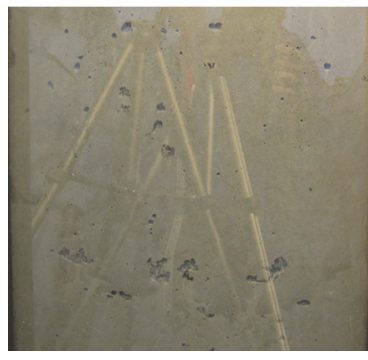

$30 \mathrm{sec}$

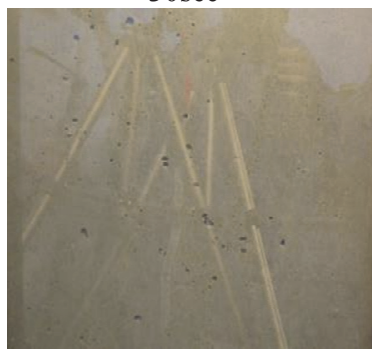

$120 \mathrm{sec}$

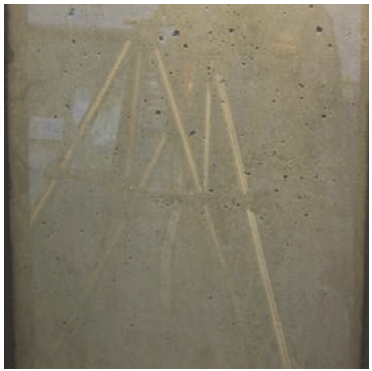

300 sec

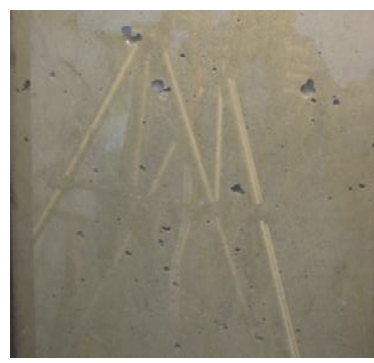

$60 \mathrm{sec}$

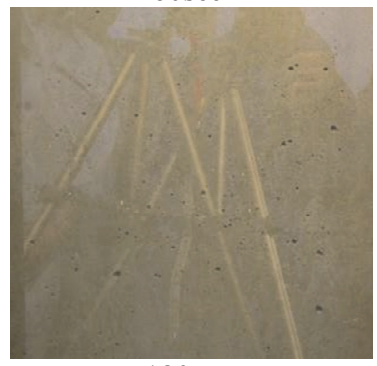

180 sec

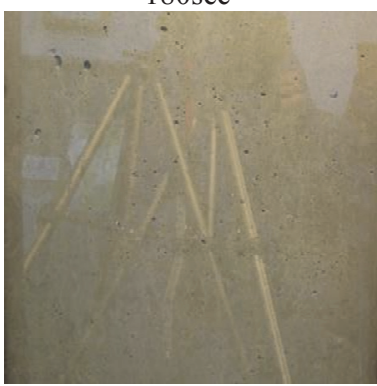

420 sec
既報の研究6),7)で用いられた感圧紙による気泡検出がで きないため, デジタル撮影画像を用いて, 従来の二值化 処理した画像解析（モノクロ解析）および気泡判定ソフ トによる画像解析（カラー解析）で検出した表面気泡の 数や面積（率）を比較した。モノクロ解析では， $5 \mathrm{~mm}$ 以 上の気泡の検出精度を基準に，グレースケール值（0〜 255）のしきい值を100に設定した．締固め開始30秒後と 180 秒後の撮影画像およびモノクロ解析とカラー解析の 結果の比較をFig.4に示す.それぞれの解析結果において 黒色部分が表面気泡と判定された箇所である. 締固め30 秒を示す画像では，180秒の画像に比べ大きな気泡がみ られる. 締固め30秒後の画像の矩形内にある $15 \mathrm{~mm}$ 程度 の大きな気泡に着目し, カラー解析とモノクロ解析の結 果を比較する (Fig.5参照). カラー解析の画像から同一気 泡内で影による色の濃淡が確認できる. カラー解析では, その色の濃淡の影響なく大きな気泡を一つの気泡とし て判定し, その周辺にある小さな気泡も別の気泡として 判定している.しかしモノクロ解析では気泡内の色の濃 淡によって一つの気泡を複数の気泡と判定しているこ とが分かる．RGB值を直接用いて表面気泡を検出するカ ラー解析では, 同一気泡内の色や影の濃淡の差異を詳細 に評価できる.一方, モノクロ解析ではカラー画像 (RGB 值）を二極化した白黒画像に変換して，しきい值を基に 表面気泡を推定するため, カラー解析より検出精度が劣 り，誤差が大きくなったものと考えられる. 
180秒の画像では同一気泡内で影の濃淡が生じるほど の大きさの気泡がないことから, Fig.4において，気泡そ のものの判定に, 両解析法の差異がほとんどみられなか った。しかし，モノクロ解析では画像左右両端のアクリ ル板に反射した影を気泡として判定していることが分 かる.

両解析法による気泡数および表面気泡面積率をそれ ぞれFig.6, Fig.7に示す.気泡数は容易に目視確認ができ, 仕上がり面の見映えに影響を与えるといわれる径 $1 \mathrm{~mm}$ 以上の気泡を対象とした. 気泡総数は解析方法や締固め 時間で差異は認められない。気泡径別に個数をみると, 30秒では解析方法別の差異はほとんどないが，180秒で はカラー解析で5 10mmが 1 個, $10 \mathrm{~mm}$ 以上が 0 個であるの に対して，モノクロ解析では5 10 $\mathrm{mm}$ が0個，10 mm以上 が4個と差異がある.Fig.4の180秒の撮影画像では，目視 でも径 $10 \mathrm{~mm}$ 以上の気泡を確認できない，Fig.7に示す表 面気泡面積率では, 30・180秒ともにモノクロ解析の方が 大きく，特に180秒の画像ではモノク口解析の表面気泡 面積率が $2.633 \%$ に対してカラー解析が $0.522 \%$ と約 5 倍の 差異が生じている。これは大きな気泡の検出誤差の影響 を受けているためと思われる.コンクリートの表面気泡 の判定にあたり，カラー画像を用いた気泡判定ソフトに よる解析を行うことで，これまでモノクロ画像解析では しばしばみられた影の濃淡による誤判定を低減するこ とができ, 表面気泡の判定精度が向上するものと判断さ れる.さらに，カラー画像解析は，表面気泡を自動判定 することから目視調査では困難であった評価者による 検出精度のバラツキを少なくし，定量評価ができる．以 上より，本研究で開発した気泡判定ソフトにおける径 $1 \mathrm{~mm}$ 以上の気泡検出精度を確認できた．次章ではこの気 泡判定ソフトを用いて検出・解析した表面気泡の結果を 基に, 振動締固め過程における表面気泡の発生特性につ いて報告する。

\section{4 振動締固め過程における表面気泡の特性}

本研究の画像解析で使用した振動締固め過程の写真を Fig.8に示すとともに，Fig.9とFig.10にそれぞれ気泡判定 ソフトを用いて検出した表面気泡の発生総個数および 気泡径別発生個数を示す. Fig.9に示寸表面気泡数は, 締 固め後120～180秒間で一旦収束傾向がみられるが，それ 以降は振動締固め時間に応じて増加している．Fig.10に は径 $1 \mathrm{~mm}$ 以上の気泡について気泡径別の発生個数をま とめた. 径1 5mmの気泡は, 締固め後60～180秒で127個 から94個に減少し，その後増加に転じ，420秒で267個と 60 秒後の約 2 倍になり, 増減傾向は気泡総数と類似して いる. 一方, 径5 10mmの気泡は, 締固め時間が長くなる につれ減少している. 径10 20 mmの気泡は，締固め後30 秒で5個，60秒で4個発生しているが，それ以降の発生は ない.このことから, Fig.9で示した表面気泡発生総数が, 一旦は収束傾向にあるが締固め時間が長くなるにつれ 増加する現象は，径1～5mmの気泡の影響が大きいとい えよう。次に最大気泡径に着目すると, 締固め開始後か

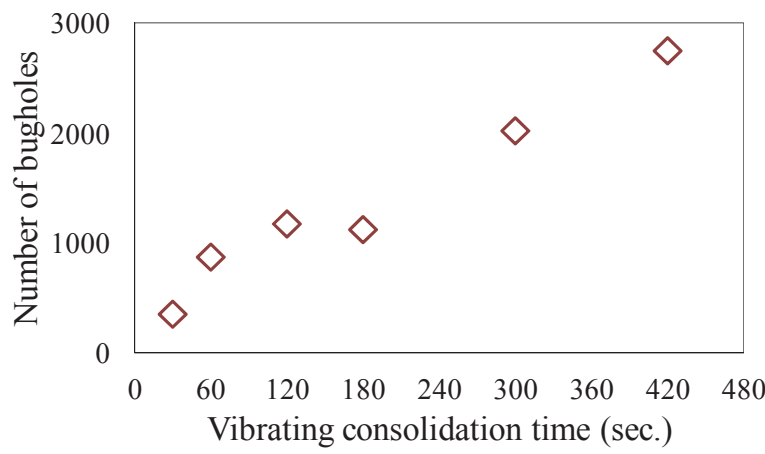

Fig.9 Number of bugholes - vibrating consolidation time.

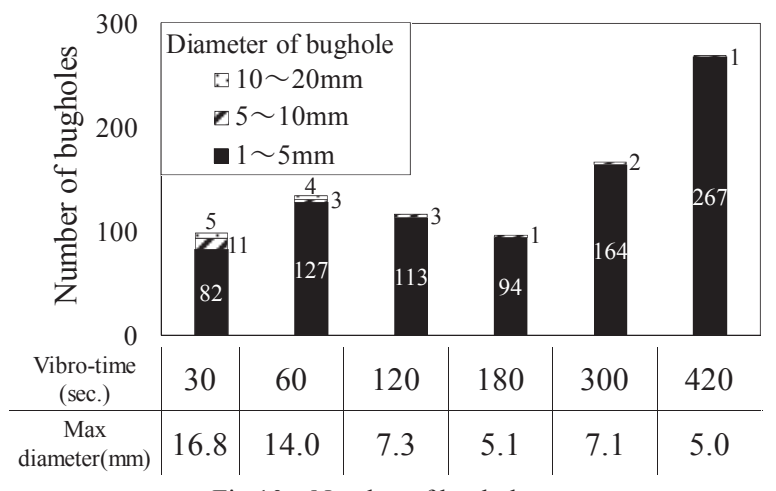

Fig.10 Number of bugholes.

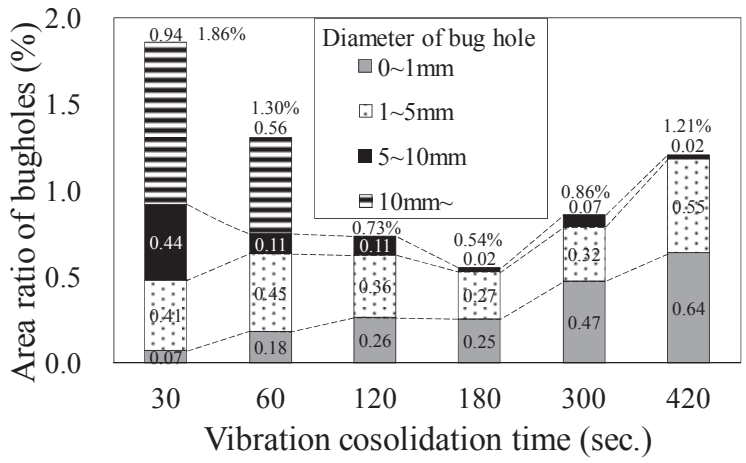

Fig.11 Area ratio of bugholes vibrating consolidation time.

ら120秒までは徐々に小さくなり，それ以降は5 10mm (本画像解析では5〜 7mm) の表面気泡が最大であった. なお，気泡の移動を連続的に観察したところ，気泡の移 動に伴うセメントペーストによるアクリル板の污れは ほとんど生じていない。これまでの研究において, 覆工 コンクリート側壁部を模擬した $30^{\circ}$ 傾斜させた型枠で は, 比較的大きな気泡よりも小さな気泡の移動速度が遅 く, 振動締固め過程において気泡がコンクリート内部か ら連続的に仕上がり面に出現することや，小さなサイズ の気泡が連結して大きな気泡になることが確認されて いる6).したがって, 振動締固め時閒が長くなるほど表面 気泡発生総数が多くなる要因の一つとして, 振動締固め 過程において気泡がコンクリート内部から連続的に仕 上がり面に出現することに加え, 仕上がり面で移動速度 が遅くなる比較的小さい気泡が残存しやすいためと考 えられる．このことは, 振動締固めの長期化による表面 気泡の低減効果に限界があることを示唆している。 
次に表面気泡面積率の経時変化をFig. 11に示す. 締固 め開始後30～180秒の間で1.86\%から 0.54\%まで減少して いるが，その後緩やかに増え，締固め後420秒では $1.21 \%$ まで増加している．気泡径別にその傾向をみると，径 0 1mmの表面気泡面積率は締固め時間が長くなるにし たがい増加している. 径1 5mmの表面気泡面積率は締固 め時間の経過に伴い締固め後180秒までは減少するもの のその後増加に転じている．増減の差は少なく，この径 を境に径5 10 mmおよび $10 \mathrm{~mm}$ 以上の気泡面積率は締固 め時間の経過に伴い減少している。また，締固め30秒後 では気泡径 $10 \mathrm{~mm}$ 以上の表面気泡面積率が $0.94 \%$ と全表 面気泡面積率の約 $50 \%$ を占めたが，径 0 ～ $1 \mathrm{~mm}$ の気泡面 積率は $0.07 \%$ と全体の $3.6 \%$ と小さい. 締固め時間 420 秒で は, 径 $10 \mathrm{~mm}$ 以上の気泡はなく, 最も大きい径5 10mmの 表面気泡率面積率が $0.02 \%$ で全体の $1.6 \%$ ，径 0 1mmが $0.64 \%$ で全体の $52.9 \%$ である，以上より，表面気泡面積率 は，締固め開始後は気泡径の大きい気泡の影響を受け， 締固め時間が長くなるにしたがい気泡径の小さい気泡 の影響を受けることが窺える。

\section{5 結訔}

本研究は，コンクリート表面気泡の低減法に寄与する ため，その基礎的研究として振動締固め過程における表 面気泡について，デジタルカラー画像を表面気泡判定y フトにより検出・解析することで，その発生特性の定量 評価を試みたものである。本研究の範囲内で得られた結 論を以下に記す。

（1） カラー画像を用いた表面気泡判定ソフトによる表 面気泡の検出は, 従来の二值化処理による検出手法 に比べ, 画像の影や色の濃淡の誤判定を低減できた。 同一気泡内で色の濃淡ができる大きさの気泡の判 定精度を向上できることが確認された。

（2）締固め過程における表面気泡発生総数は，締固め 120〜180 秒間で収束傾向を示したが，その後締固 め時間の経過とともに増加した。これは，気泡径 $5 \mathrm{~mm}$ 以上の気泡は減少しているものの, 径 1〜 $5 \mathrm{~mm}$ の気泡が増加したためである。径 $10 \mathrm{~mm}$ 以上の気 泡は締固め 60 秒後でなくなり，これ以降の最大気 泡は径 5〜 7mm であった。

（3）振動締固め過程における表面気泡面積率は，180 秒 までは $1.86 \%$ から $0.55 \%$ と約 30\%まで減少したが, その後増加に転じ， 420 秒後では $1.21 \%$ となった。
（4）締固め開始 30 秒後では，気泡径 $10 \mathrm{~mm}$ 以上の表面 気泡面積率が全体の約 50\%を占めるが, 420 秒後で は気泡径 $10 \mathrm{~mm}$ 以上の表面気泡がなくなり，気泡 径 0 1mm の気泡面積率が全体の $52.9 \%, 1 \sim 5 \mathrm{~mm}$ が 45.5\%を占めた．表面気泡面積率は，締固め初期で は気泡径が大きい気泡, 締固め時間が長くなるほど 気泡径の小さい気泡の影響を受けることがわかっ た

今後，効率良く表面気泡を低減するには，振動締固め に加え，移動速度が遅い $5 \mathrm{~mm}$ 程度以下の小さな気泡を 低減・除去することが有効と考える.

\section{参 考 文 献}

1) N. Sakata, K. Watanabe and A. Hosoda, "The improvement of the quality of the concrete structure by a new evaluation method on the surface quality using the visual test", JCI, Vol.50, No.7, pp.601-606 (2012).

2) Standard of the Japanese society for non-destructive inspection, NDIS, pp.6-9 (2012).

3) K. Katano, T. Kawanishi and R. Chikamatsu, "Technical skills for acquirement of aesthetics concrete surface", Report of Obayashi Corporation Technical Research Institute, No.76, pp.1-6 (2012)

4) S. Kawabe, T. Okajma, M. W. Tjaronge and M. Muto, "Proposal of horizontal vibration method for manufacturing precast concrete", Proceeding of JCI,Vol.21, No.2, pp.943-948 (1999).

5) I. Yoshitake, H. Komure, M. Kakehi. A. Hiraoka and Y. Inagawa. "Questionnaire investigation of surface deterioration of lining concrete in NATM tunnel", Proceedings of ASEA-SEC1, pp.221-225 (2012).

6) M. Hirano, T. Maeda, H. Honma, S. Harada, T. Tanase and I. Yoshitake, "Fundamental experiment for reducing bugholes on sidewall of tunnel lining concrete", Journal of Japan Society of Civil Engineers, Ser. F1 (Tunnel Engineering), Vol.71, No.2, pp.95-105 (2015).

7) M. Hirano, I. Yoshitake, A. Hiraoka and Y. Inagawa, "Evaluation of air bubbles distributed on concrete surface of side wall of tunnel lining", Cement Science and Concrete Technology, No.67, pp.252-257 (2014).

8) T. Maeda, H. Honma, M. Hirano and I. Yoshitake, "Permeability of tunnel lining with air/water bubbles on concrete surface", Proceeding of ASEA-SEC2, pp.321325 (2014). 